\title{
IDEOLOGI, KEYAKINAN, DOKTRIN DAN BID'AH KHAWARIJ: Kajian Teologi Khawarij Zaman Modern
}

\author{
Sukring \\ Universitas Halu Oleo Kendari \\ e-mail: sukring_69@yahoo.co.id
}

\begin{abstract}
Islam is a religion of balance and moderation, Muslim are supposedly the people of the middle or the neutral people. But in fact, this word means not to be excessive (moderate). Its modesty appears in doctrine and morals. That is the main characteristic of Islam. Those who are far away from moderation have indeed moved away from the spirit of Islam. Throughout ages there have been always extreme groups. Consequently, they will be shunned by people, although they outwardly practice good deeds and are devout. In this case, the most obviously extreme group was the Khawarij. Killing Muslims deemed valid by the Khawarij. Even today Khawarij still uses the name of Islam and raised slogans to establish a divine order. However, all of their actions and steps actually violate the teachings of Islam. Khawarij passed through indelible traces in the history. Nevertheless, Nowadays, there are groups showing up again in the world and in the new paradigm of Khawarij by murder,rebellion in a legitimate government, and terrorism. The scholars indicate they are modern Khawarij.
\end{abstract}

\begin{abstract}
Abstrak: Islam adalah agama seimbang dan moderat, sebagai umat pertengahan, perantara, atau bangsa yang netral. Namun faktanya, kata ini bermakna tidak berlebih-lebihan (moderat). Kesederhanannya tampak dalam doktrin dan akhlak. Itulah ciri utama dari Islam. Mereka yang menjauhkan diri dari sikap moderat telah menjauh dari semangat Islam yang sebernarnya. Sepanjang zaman akan selalu muncu kelompok-kelompok yang berhaluan ekstrim. Sebagai konsekwensi, mereka akan dijauhi umat, meski secara lahiriah menampilkan amalan Islam dan taat dalam beragama. Dalam hal ini kelompok yang paling kentara adalah Khawarij. Membunuh orang Muslim dianggap sah oleh Khawarij. Bahkan hari ini Khawarij menggunakan nama Islam dan mengangkat sloganslogan untuk membangun tatanan Ilahi. Akan tetapi, semua tindakan dan langkah mereka sejatinya merupakan pelanggaran terhadap ajaran Islam. Ketika para pendukung Khawarij tidak memiliki dalil yang sah untuk tindakan mereka. Aliran Khawarij telah berlalu dengan jejak yang tak terhapuskan dalam sejarah. Namun dalam perkembangan zaman, kelompok ini mulai kembali dalam pentas dunia, dalam paradigma baru dengan melakukan pembunuhan, pemberontakan pada pemerintah yang sah, dan terorisme. Para ulama mengindikasikan mereka adalah kelompok Khawarij zaman modern.
\end{abstract}

Keywords: ideologi; doktrin; bid'ah Khawarij; zaman modern 


\section{A. Pendahuluan}

Dalam catatan sejarah, untuk pertama kalinya, Khawarij muncul sejak zaman Rasulullah. Kemudian ide mereka ini menemukan momentumnya di zaman Usman ibn Affan, sampai zaman Ali ibn Abi Thalib. Pada zaman Ali mereka menjadi kelompokyang sangat kuat dan terorganisir.

Sekte Khawarij berarti kelompok yang keluar dari satuan kelompok terdahulu. Nama itu diberikan kepada pengikut Syiah yang menarik dukungan terhadap kepemimpinan Ali dan keturunannya. Karena tidak setuju dengan sikap Ali dalam menerima arbitrase sebagai jalam menyelesaikan perselisihan tentang khalifah dengan Mu'awiyah ibn Abi Sufyan. Mereka beranggapan bahwa tak satu sekte pun yang berhak atas kepemimpinan umat, tidak Bani Umayah, tidak Ali dan keturunannya, juga Bani Abbas, semua pihak tersebut halal darahnya untuk dialirkan. Sepintas dapat dianggap bahwa mereka cenderung anarkis, namun mereka sebenarnya demokratis.

Dalam lapangan politik mereka mempunyai paham yang berbeda dengan paham yang di waktu itu. Menurut keyakinan mereka khalifah atau imam harus dipilih secara bebas oleh seluruh umat Islam. Yang berhak menjadi khalifah bukanlah anggota suku bangsa Quraisy saja, bahkan bukan hanya orang Arab, tetapi siapa saja yang sanggup asal orang Islam. Khalifah yang terpiliha akan terus memegang kekuasaannya selam ia bersikap Adil dan menjalankan syariah Islam. Tetapi kalau ia menyeleweng dari ajaran-ajaran Islam ia wajib dijatuhkan atau dibunuh. ${ }^{1}$ Pada saat itulah Usman dan Ali, bagi mereka telah menjadi kafir. Demikian pula halnya Mu'awiyah, Amr ibn al-'Ash, Abu Musa al-Asy'ari serta semua orang yang mereka anggap telah melanggar syariah agama.

Di sini kaum Khawarij memasuki persolan kufr. Siapa yang disebut kafir dan keluar dari Islam. Siapa yang disebut mu'min, dan dengan demikian tidak keluar dari, tetapi tetap dalam Islam. persoalan-persoalan ini buka lagi merupakan persoalan politik, tetapi persoalan politik. Pendapat tentang siapa yang sebenarnya masih Islam dan siapa yang keluar dari Islam dan menjadi kafir, sehingga muncullah golongan dalam kalangan Khawarij.2 105.

${ }^{1}$ Muhammad Ahmad Abu Zahra, al-Mazāhib al-Islāmiyyah (Kairo: Maktabah al-Adab, t.th.), h.

${ }^{2}$ Harusn Nasution, Teologi Islam: Aliran-aliran Sejarah Analisa Perbandingan (Jakarta: UI Press, 1986), h. 12. 
Sebagai kekuatan politik golongan Khawarij telah tersebut selama abad Sembilan dan sepuluh di kawasan Timur tengah maupun Afrika yang dikuasai golongan Syiah, oleh alas an ekonomi maupun politik.

Perlu diketahui kaum Khawarij kebanyakan dari orang-orang Arab Badui yang hidup di padang pasir dan keadaan yang serba keras, membut mereka bersifat sederhana dalam alam pikiran, keras dalam pendirian, berani dalam bertindak, dan mandiri. Mereka berpandangan sempit, fanatik, kuran toleran terhadap perbedaan, tidak terbuka karena kurang berilmu pengetahuan. Akibatnya rawan akan terjadinya pengelompokan baru. Mereka mudah menuduh kafir atau musrik terhadap siapa saja yang tidak mengikuti mereka. Kafir atau musyrik dengan sendirinya halal darahnya untuk dialirkan.

Ajaran-ajaran Islam yang terdapat dalam al-Qur'an dan hadis, mereka artikan menurut lafadnya dan harus dilaksanakan sepenuhnya. Oleh karena itu iman dan paham mereka merupakan iman dan paham mereka yang sederhana dalam pemikiran. Sikap fanatik ini membuat mereka tidak mentolerir penyimpangan terhadap ajaran Islam menurut paham mereka, walaupun hanya penyimpangan dalam bentuk kecil. ${ }^{3}$

Di sinilah kemudian, kelompok Khawarij menjadi beberapa golongan, ada golongan yang ekstrim dan radikal, sesunggunya mereka telah hilang dalam sejarah, golongan al-Ibadiah ini yang yang masih ada sampai sekarang dan terdapat di Zanzibar, Afrika Utara, Umman dan Arabia Selatan. Ajaran-ajaran ekstrim mereka masih mempunyai pengaruh walaupun tidak banyak dalam masyarakat Islam sekarang.

Kelompok Khawarij yang ekstrim, secara umum telah muncul kembali dan melakukan kekerasan, dan mengklaim tindakannya sebagai amaliah Islam. Hanya karena argumen keagamaan mereka yang terlampau ekstrim dan munafiq. Kemudian mereka menghalalkan pertumpahan darah di kalangan kaum Muslimin, yang berkaitan dengan aksi Khawarij lama dengan para terorris pada zaman sekarang.

\section{B. Sekilas tentang Khawarij}

Sebelum kita mengkaji simbol, keyakinan, dan doktrin Khawarij, maka akan dikemukakan definisi Khawarij menurut ulama salaf.

3Ibid, h. 13.

JURNAL THEOLOGIA — Volume 27, Nomor 2, Desember 2016 
Muhammad ibn 'Abdu al-Karim al-Syahrastān, mengatakan istilah Khawarij dipergunakan untuk menyebut kelompok masyarakat yang memberontak dan tidak mengakui keabsahan imam yang, baik pada zaman sahabat di zaman alKhulafä' al-Rāshidīn, atau pada zaman tabi'in dan para imam (pemimpin) di sepanjang zaman. ${ }^{4}$

Imam al-Nawawi, menjelaskan Khawarij adalah satu kelompok ahli bid'ah yang meyakini bahwa orang yang melakukan dosa besar menjadi kafir dan kekal di neraka. Oleh karena itu mereka membangkang terhadap imam dan tidak mau menghadiri salat Jum'at dan salat berjamaah. ${ }^{5}$

Ibnu Taimiyah menyatakan mereka adalah kelompok yang menghunuskan pedang dan melakukan peperangan. Mereka membangkan terhadap jamaah ketika memerangi manusia. Adapun hari ini keberadaan mereka tidak diketahui mayoritas orang. Maksud mereka terlepas dari agama adalah mereka keluar dengan menghalalkan darah dan harta kaum Muslimin. ${ }^{6}$ Ibnu Taimiyah menyatakan bahwa kaum Khawarij ini bukanlah kelompok perang tertentu yang dikenal dalam sejarah. Justru mereka akan senantiasa eksis hingga zaman Dajjal.7 Maksud penyebutan secara khsusus oleh Nabi untuk kelompok yang muncul pada zaman ali ibn Abi Thalib adalah dikarenakan ciri-ciri yang pada mereka. Setiap kelompok yang memiliki ciri-ciri yang sama maka dikelompokkan dengan mereka. Ini karena penyebutan secara khsusus bukan berarti hukumannya hanya berlaku pada mereka, tetapi untuk kebutuhan mendeskripsikan mereka kepada para sahabat pada saat itu. ${ }^{8}$

Ibnu Hajar Asqalani berpendapat, Khawarij adalah kata jamak dari kata kharijah artinya sekolompok orang. Mereka adalah ahli bid'ah. dinamai demikian karena mereka telah keluar dari Islam dan membelot dari pemimpin kaum Muslimin. ${ }^{9}$ 2000), 114 .

${ }^{4}$ Muhammad ibn 'Abdu al-Karim al-Shahrastān, al-Milāl wa al-Niḥāl (Beirut: Dār al-Ma'rifah,

${ }^{5}$ Muhyi al-Dīn Yahya ibn Syaraf al-Nawāwi, Sharḥu al-Nawāwi 'alā Shahīh Muslim (Beirut: Dār Ihya al-Turăts, 1392 H.) h, 10:51. 222.

${ }^{6}$ Aḥmad ibn 'Abdi al-Ḥālim ibnu Taimiyah, al-Nubuwwat (Beirut: Dār Al-Kitāb Al-'Arabī, 1985), h.

${ }^{7}$ Ahmad ibn 'Abdi al-Ḥālim ibnu Taimiyah, Majmū' al-Fatāwā, (t.t.p.: Maktabah, Ibnu Taimiyah, t.th.), 28, h. 495-496.

${ }^{8} \mathrm{Ibid}$.

9Ibnu Ḥājar Ahmāàd ibn 'Ali al-Asqālanī, Hadyu al-Sari: Muqaddima Fatḥ Bārī (Beirut: Dār alMa'rifah, t.th.), 12, h. 283. 
Ibnu Nujaim al-Hanafi berkomentar, Khawarij adalah suatu kaum yang memiliki kekuatan militer, mereka membelot dari imam dengan interpretasi sendiri. Mereka berpandangan bahwa imam itu batil dan kufur atau melakukan kemaksiatan yang harus diperangi. Mereka menghalalkan dan harta umat Islam dengan interpretasi itu. ${ }^{10}$

Dari definisi yang dikemukakan para ulama salaf tersebut di atas, bahwa kelompok Khawarij yang menafikan imam (pemimpin) umat Islam. Mereka menghalalkan darah kaum Muslimin karena menganggap kufur dan melakukan kemaksiatan. Kaum Khawarij adalah kelompok ekstrimis yang melakukan pemberontakan, mereka pelaku bid'ah yang memiliki ciri-ciri khusus. Kelompok ini diindikasikan sebagai kaum Khawarij yang muncul sepanjang zaman.

Orang-orang Khawarij di zaman dahulu adalah orang-orang yang taat beribadah, rajin berpuasa, dan rajin membaca al-Qur'an, dan bahkan mereka mampu melebihi para sahabat. Khawarij modern tidak jauh berbeda dengan para pendahulunya. Lahiriahnya, mereka Nampak sebagai orang-orang shalih dan terlihat ahli dalam masalah hukum Islam. Namun bathinnya, mereka adalah korban kejahatan seperti ekstrimisme, radikalisme, serta keyakinan-keyakinan sesat yang merugikan umat Islam, haus perang dan membunuh hingga sangat merugikan umat Islam.

\section{Perkembangan Teologi Khawarij pada Zaman Pemerintahan Khalifah Usman ibn Affan, dan Khalifah Ali ibn Abi Thalib}

Terjadi banyak kebingungan, kesedihan, dan kekalutan dalam tubuh umat Islam pasca wafatnya Rasulullah, termasuk kegelisahan para sahabat, siapa pengganti Nabi setelah meninggal dunia. yang kemudian muncul para Nabi palsu, banyak orang murtad, kelompok yang menolk membayar zakat, serta ada kaum yang menoloak rukun Islam. Para ahli sejarah menggambarkan Usman sebagai orang yang lemah dan sanggup menentang ambisi kaum keluarganya yang kaya dan berpengaruh itu, Usman mengangkat mereka menjadi gubernurgubernur di daerah yang tunduk pada pemerintahan Islam.Tindakan-tindakan politik yang dijalankan Usman menimbulkan reaksi yang tidak menguntungkan dirinya, perasaan tidak senang muncul di daerah-daerah Di antara mereka yang t.t.), h. $24: 84$.

${ }^{10 ` B a d r i ~ a l-D i ̄ n ~ a l-' A i n i, ~ U m d a h ~ a l-Q a r i ~ S h a r h ̣ ~ S ̦ a h ̣ i ̣ h ~ a l-B u k h a ̄ r i ̄ ~(B e i r u t: ~ D a r ~ I h y a ~ a l-T u r a t s ~ a l-' A r a b i, ~}$ 
menganut keyakinan ini adalah Khawarij yang mempromosikan pemahaman sesat mereka, eksploitasi kekacauan, dan mulai mengorganisir kelompoknya untuk menjadi sebuah kekuatan. Mereka yang membuat kosnpirasi melawan Usman, sehingga akhirnya Usman terbunuh di akhir pemerintahannya oleh orang-orang yang berkeyakinan Khawarij. Di antara yang paling terkemuka di kalangan mereka adalah Abdullah ibn Saba'. Inilah awal mula pemberontakan terhadap pemerintah Islam.

Ulama-ulama menjelaskan bahwa ini adalah fitnah besar pertama, kekacauan terjadi ketika Utsman ibn Affan terbunuh. Umat Islam yang terkena hasutan terbagi menjadi dua kelompok salah satunya yang menjadi kelompok yang berinisiasi melakukan pembunuhan berdarah dan melakukan beragam praktik bid'ah terhadap agama. Itulah yang mendasari munculnya kelompok Khawrij setelah perang siffin di zaman pemerintahan Ali ibn Abi Thalib.

Agenda besar kaum Khawarij adalah mengacaukan keutuhan Negara Islam dan atas nama agama. Jika kita mengkaji secara kritis sejarah Khawarij dapat dilihat selalu ada gerakan kekerasan yang menolak dialog dan perjanjian damai untuk menghentikan sengketa, seperti menolak kebijakan tahkim (mengangkat Khalifah) yang dilakukan Ali ibn Abi Thalib sebelum perang Siffin. Selama konflik perang terjadi elemen Ali dalam prajurit perang tetap mendukungnya. Akan tetapi setelah peristiwa tahkim yang diambil Ali untuk menghindari pertumpahan darah, mereka menolak Ali dan melakukan desersi militer. Mereka menyebut Ali sebagai orang kafir dan umat Islam dan atas nama jihad. Untuk mengorganisir kekuatan ini mereka menggunakan motto dan propaganda "Tidak ada hukum kecuali hukum Allah." Ketika Ali mendengar slogan ini, Ali berkata: "Kalimat yang benar tapi yang dimaksudkan adalah perkara batil."11

Khawarij mengambil inisiasi pemberontakan kepada Ali dan aktivitas mereka dipusatkan di Ḥarūrah sebuah tempat di perbatasan Irak. Mereka menuduh Ali sebagai seorang musyrik, ahli bid'ah bahkan menyebut kafir serta mendeklarasikan pemberontakan melawan Ali. Kaum Khawarij mengambil keputusan untuk membunuh mereka, termasuk Mu'awiyah, Amr, dan Abu Musa. Menurut sejarah orang ditugasi membunuh Ali yang berhasil dalam tugasnya. h. 299.

11Muhammad Tahir al-Qadri, Fatwa tentang Terorisme dan Bom Bunuh Diri (Jakarta: LPPI, 2014), 
Inilah sinopsis asal mula mereka. Mereka muncul pada zaman Pemerintahan Ali ibn Abi Thalib, sehingga ada di kalangan mereka Abdul al-Rahman ibn Muljim yang membunuh Ali ketika akan melaksanakan shalat Subuh. Maka muncullah Khawarij di Irak pimpinan Nafi ibn al-Azraq dan di Yamamah pimpinan Najdah ibn Amir. Najdah menambahkan akidah Khawarij bahwa orang tidak keluar dan memerangi umat Islam. Maka dia kafir sekalipun seakidah dengan Khawarij. Mereka juga mengkafirkan yang tidak menyuruh kepada kebaikan dan mencegah kemungkaran jika mereka mampu. Jika mereka tidak mampu, maka dia telah melakukan dosa besar. Hukum bagi pelaku dosa besar adalah kafir menurut pandangan mereka.

Cara berpikir Khawarij dapat dilihat dalam surat yang ditulis Ali ibn Abi Thalib; jelaskan kepada kami, alasan apa yang menyebabkan kalian menghalalkan untuk memerangi kami dan membelot dari jamaah. Mempersenjatai bekas hamba sahaya kalian dan menyerang orang-orang dengan memenggal kepada mereka? Sesungguhnya perbuatan ini adalah kerugian yang sangat nyata. Demi Allah, seandainya kalian membunuh seekor ayam atas dasar semua ini, pastilah dosanya sangat besar di sisi Allah, maka bagaimana dengan membunuh nyawa manusia yang diharamkan oleh Allah. ${ }^{12}$

Kutipan ini secara jelas menunjukkan bagaimana Khawarij menyebut para sahabat Rasulullah dan umat Islam pada umumnya sebagai orang-orang kafir dan musyrik. Selain menganggap halal membunuh para sahabat dan umat Islam, bahkan hal ini merupakan mandat dari mazhab mereka.

Lambat laun kaum Khawarij pecah menjadi beberapa sekte, konsep kafir turut pula mengalami perubahan. Persoalan orang berbuat dosa inilah yang mempunyai pengaruh besar dalam pertumbuhan teologi selanjutnya dalam Islam. Persoalannya ialah apakah ia bisa dipandang orang mukmin ataukah ia sudah menjadi kafir karena berbuat dosa itu.

Persoalan ini menimbulkan tiga aliran teologi dalam Islam. ${ }^{13}$ Pertama, aliran Khawarij yang mengatakan bahwa orang berdosa besar adalah kafir, dalam arti keluar dari Islam atau murtad dan oleh karena itu wajib dibunuh. Kedua, aliran Murji'ah yang menegaskan bahwa orang yang berbuat dosa besar

12‘Ali ibn Muhammad Ibn al-Athīr, al-Kāmil fi al-Tarīk(Beirut: Dār Shādir 1979), h. 3: 220.

${ }^{13}$ Harun Nasution, Teologi Islam..., h. 7. 
tetap masih mukmin dan bukan kafir. Adapun soal dosa besar yang dilakukannya, terserah kepada Allah untuk mengampuni atau tidak mengampuni. Ketiga, aliran Mu'tazilah, aliran ini tidak menerima pendapat di atas. Bagi mereka orang yang berbuar dosa besar bukan kafir tetapi bukan pula mukmin. Orang serupa ini kata mereka mengambil posisi di antara kedua posisi mukmin dan kafir yang dalam bahasa Arabnya terkenal dengan istilah al-manzilah bain manzilatain (posisi di antara dua posisi).

Al-Shahrastān mengatakan Khawarij memiliki kelompok-kelompok terpenting adalah: al-Muhakimah, al-Azariqah, al-Najdiyah, al-Baihasiah, al-Ajaridah, al-Tha'libah, al-Sufriah dan beberapa kelompok lainnya. Semua kelompok Khawarij sependapat bahwa mereka tidak mengakui Kekhalifahan Usman maupun Ali, mereka mendahulukan kekuatan (ibadah) dari segala-galanya. Mereka menganggap tidak sah perkawinan terkecuali dengan kelompoknya, mereka mengkafirkan orang yang melakukan dosa besar dan tidak wajib menaati imam yang menyalahi sunnah..$^{14}$ Lebih lanjut, al-Shahrastān menjelaskan secara rinci kelompok-kelompok tersebut, yaitu:

1. Al-Muhakimah. Kelompok Muhakimah adalah kelompok yang tidak menaati Ali ibn Abi Thalib setalah terjadinya tahkimm (arbitrase)

2. Al-Zariqah, kelompok ini pendukung Abu Rasyid Nafi ibn al-Azraq yang memberontak terhadap pemerintahan Ali ibn Abi Thalib. Ia melarikan diri dari Basrah ke Ahwaz dan kemudian berhasil menguasai Ahwaz dan daerahdaerah sekelilingnya seperti Kirman di masa Abdullah ibn Zuhair sesudah membunuh Gubernurnya.

3. Al-Najdah al-Azariah adalah kelompok yang mengikuti pemikiran seseorang yang bernama Najdah ibn Amir Al-Hanafi yang dikenal dengan nama 'Ashim yang mentap di Yaman. Dalam perjalanannya menemui kelompok Azariqah di tengah jalan bertemu dengan Fudaik 'Athiah ibn al-Aswad al-Hanafi yang tergabung dalam kelompok yang membangkang terhadap Nafi ibn Azraq. Dibertahukan kepadanya tentang inti perselisihan mereka dengan Nafi mengenai hukum orang tidak ikut pertempuran, karena para pembangkang mengangkat Najdah menjadi pemimpin dengan gelar 'Amnirul Mu'minin. Namun beberapa waktu kemudian mereka berselisih dengan Najdah. Mereka menyalahkan Najdah, dan ada orang yang mengkafirkan Najdah.

14 al-Shahrastān, al-Milāl wa al-Niḥāl, h. 102. 
4. Al-Baihasiah, kelompok ini mengikuti pendapat Abu Baihas al-Haisham ibn Jabir salah seorang dari suku Bani Saad Dhubai'ah. Di masa pemerintahan Khalifah Al-Qalid dan selalu di cari-cari oleh al-Hajjaj namun dia berhasil melarikan diri dan bersembunyi di Madinah, namun dapat di tangkap oleh Usman ibnu Hayam al-Muzani. Sementara menunggu keputusan Khalifah alWalid ia dipenjarakan kemudian di hukum dengan memotong kedua tangan dan kakinya dan seterusnya di bunuh.

5. Al-Jaridah, kelompok ini di pimpin oleh Abd al-Karim 'Araj yang isi ajarannya mirip dengan al-Najdah. Menurutnya kita tidak boleh mengatakan kafir atau Muslim terhadap anak seorang Muslim sampai ia telah diajak memeluk Islam. Sedangkan anak orang kafir bersama orang tuanya berada di dalam neraka.

6. Al-Tha'alibah, kelompok ini di pimpin oleh Tsa'labah ibn Amir yang dahulunya sependapat dengan Abd Karim ibn Araj, menurut pendapatnya anak tidak bertanggungjawab semenjak kecil sampai usia menjelang dewasa.

7. Al-Ibaḍaiyyah, kelompok ini adalah pengikut 'Abdullah ibn 'Ibadh yang memberontak terhadap pemerintahan Khalifah Marwan ibn Muhammad.

8. Al-Ṣufriyyah, kelompok ini nama kelompok yang mengikuti pemikiran Zayad ibn Ashfar. Pemikirannya berbeda dengan pemikiran yang berkembang di kalngan Khawarij yang lain, seperti, al-Azariqah, an-Najdah dan alIbadhiyyah. ${ }^{15}$

\section{Ideologi Khawarij}

Indikasi menunjukkan kepada kita bahwa orang jahat dan berpikiran dangkal kadang-kadang bersatu dan bercampur baur dalam sistem sosial yang dangkal pula tentang ajaran dan visi agama. Mereka hanya melihat tampilan luar perilaku agamanya. Pada gilirannya, mereka menanamkan pada orang ini sebuah keyakinan sombong bahwa mereka pemeluk Islam dan perwujudan sejatinya. Mereka merasa paling dekat dengan Allah seraya menganggap Muslim yang lain sebagai orang kafir dan pelaku maksiat. Mereka meyakini, bahwa mereka memiliki hak untuk memaksa orang lain untuk mengikuti versi mereka, sejatinya mereka telah melupakan firman Allah dalam QS. al-Nahl [16]: 125.

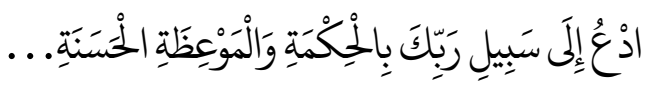

15Ibid., h. 102-122. 
Serulah (manusia) kepada jalan Tuhanmu dengan hikmah dan pelajaran yang baik...

Setan telah menabur benih takabur dalam hati mereka. Pada gilirannya mengakibatkan meraka memandang suci diri mereka sendiri. Sedangkan orang lain adalah makhluk yang kotor, sekalipun orang itu Muslim. Mereka yakin, bahwa mereka berhak memaksa orang lain untuk menyakini apa yang mereka yakini. Dan karena setan telah membentuk mereka dengan gagasan "tanpa cacat" ini, mereka pun kemudian percaya bahwa mereka bebas untuk menggunakan cara apa saja yang mereka mampu, untuk membawa orang lain agar sekeyakinan dengan mereka atau membumihanguskannya.

Paradigma semacam ini, membuat mereka tega membunuh, menebar terror, menjarah kekayaan, dan milik orang lain, tanpa merasa takut atau bersalah. Menurut pemahaman dangkal mereka, apapun yang mereka lakukan itu adalah rangkain jihad. Al-Qur'an menginformasikan kepada kita bahwa mereka adalah termasuk orang-orang yang paling merugi di hari kiamat. Firman Alaah dalam QS. al-Kahfi [18]: 103-104.

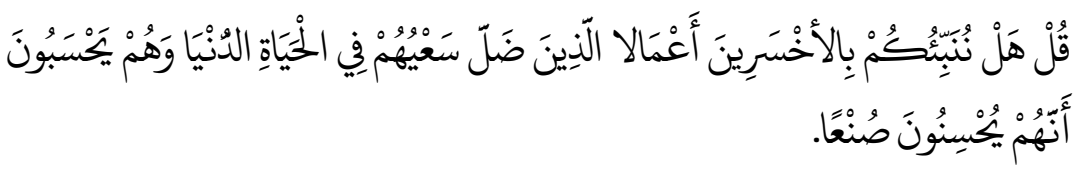

Katakanlah: "Apakah akan Kami beritahukan kepadamu tentang orangorang yang paling merugi perbuatannya?" Yaitu orang-orang yang telah sia-sia perbuatannya dalam kehidupan dunia ini, sedangkan mereka menyangka bahwa mereka berbuat sebaik-baiknya.

Imam al-Shahrastānī, berkomentar tentang sesatnya ideologi dan keyakinan mereka kaum Khawarij. Kelompok terbesar Khawarij ada enam: AlAzariqah, al-Najadat, al-Ijaradah, al-Tha'alibah, al-Ibadiyyah, dan al-Safariyyah. Yang lainnya adalah cabang-cabangnya. Mereka berpendapat bahwa membelot dari imam yang menyalahi sunnah adalah kewajiban. Mereka adalah kaum pembelot dari Amir al-Mukminin 'Ali ketika melakukan arbitrase. ${ }^{16}$

Ibnu Ḥajar al-Asqalānī, berkata dalam kutipannya, dari Ibnu Al-'Arabī; Khawarij itu ada dua kelompok, pertama berkeyakinan bahwa sesungguhnya

16 Ibid., h.115. 
Usman, 'Ali, pasukan perang Jamal dan Siffin serta setiap orang yang menerima arbitrase adalah kafir. Kedua, berkeyakinan bahwa pelaku dosa besar adalah kafir dan kekal di neraka. Najdah kemudian menambah akidah Khawarij bahwa orang yang tidak keluar dan menyerang umat Islam adalah kafir walaupun seakidah.

Alasan kenapa kaum Khawarij disebut juga gerakan Harüriyyah adalah karena kelompok pertama yang mengorganisir ideologi ini berkumpul di wilayah Hārūrāh pada zaman kekhalifahan 'Ali ibn Abi Thalib. Syabbīr Ahmad 'Usmānī I berkata; perkataannya, dari al-Harūriyyah sampai akhir mereka adalah Khawarij, bentuk jamak dari dari kata khārijah, yaitu suatu kelompok ahli bid'ah. Dinamai demikian karena merek keluar dari agama dan keluar dari pemimpin ibad umat Islam. Latar belakangnya adalah sesungguhnya sebagian penduduk Iraq mencela perilaku sebagian kerabat dekat 'Usman, mereka sering dijuluki al-Qurra, karena mereka sangat tekun dalam membaca al-Qur'an dan berribadah. Hanya mereka menakwilkan al-Qur'an tidak sesuai dengan maksudnya. Mereka bersikukuh dengan pemikiran mereka dan terlihat sangat suhud serta khusyu dan lain-lain. ${ }^{17}$

Akidah kaum Khawarij bahwa orang yang tidak keluar dan memerangi umat Islam, maka dia kafir sekalipun seakidah dengan Khawarij. Mereka juga meengkafirkan orang tidak menyeruh kebaikan dan mencegah kemungkaran jika mereka mampu. Jika merek tidak mampu, maka dia telah melakukan dosa besar. Hokum bagi pelaku dosa besar adalah kafir menurut pandangan mereka.

\section{E. Doktrin Khawarij}

Kelompok Khawarij menggunakan doktrin al-Qur'an dan doktrin agama dalam membangun fanatismenya. Mereka akan memanfaatkan sentiment ekstrim kepada sebagian kaum Muslimin yang kurang berilmu dan tidak berdaya. Kemudian menafsirkan al-Qur'an secara menyimpang. Dengan cara ini, mereka menghasut orang-orang untuk berani untuk melakukan pembataian. Agar motivasi mereka terbangun dengan baik. Khawarij selalu membangun opini syurga para pengikutnya, jika mati akan mendapat balasan surga. Dengan demikian secara mental mereka mempersiapkan para pengikutnya untuk siap membunuh atau terbunuh.

${ }^{17}$ Shabbīr Aūmad 'Usmānī, al-Fath al-Muînn bi Sharh Shahih Muslim (Damaskus: Dār al-Qalam, 2006), h. 5;158

JURNAL THEOLOGIA — Volume 27, Nomor 2, Desember 2016 
Jika dianalisis metode dan aktivitas Khawarij zaman sekarang, dapat dilihat bahwa pangikutnya terdiri dari orang yang belum dewasa, muda, serta otaknya telah dicuci, serta memiliki operandi seperti Khawarij lama. Mereka disesatkan oleh pendangan tentang Islam secara dangkal. Di sisi lain mereka berani membunuh Muslim tanpa merasa berdosa dan menyesal. Doktrin Khawarij menganggap darah sebagai barang murahan, hal ini menjelaskan bahwa orang yang dengan mental seperti ini akan terus hidup, dari zaman ke zaman lain, maka mudah untuk mengindikasikan neo-Khawarij karena mereka menggunakan cara-cara yang sama dengan Khawarij lama. Jika Khawarij lama melakukan pembunuhan dengan keji, memberontak pada pemerintah yang sah, membunuh warga yang sedang beribadah, menganggap perbuatan kejinya itu sebagai jihad. Maka Khawarij modern pun melakukan hal yang sama. Semua aksi yang mereka klaim dilakukan mujāhidūn, faktanya adalah kelanjutan dari doktrin dan ideologi Khawarij.

Para ulama klasik dan ulama kontemporer sepakat bahwa Khawarij adalah kelompok yang jahat, mereka durhaka kepada Allah dan Rasul-Nya. Sekalipun mereka shalat, shaum, membaca al-Qur'an, menyeruh kebaikan dan mencegah kemungkaran. Akan tetapi hal itu tidak memberi manfaat apapun, kerana mereka menafsirkan al-Qur'an berdasarkan hawa nafsu dan menyampaikan hal keliru kepada umat Islam. Allah dan Rasul-Nya, al-Khulafä' al-Rāshidūn, seluruh sahabat Nabi dan generasi berikutnya telah mengingatkan akan bahaya Khawarij. Khawarij adalah penjahat yang paling keji. Demikian juga sekte-sekte Khawarij lainnya. Dahulu mapun sekrang memiliki doktrin yang sama. Sesorang yang melihat Khawarij rela membelot dari pemerintah yang adil atau zalim, mengumpulkan massa, menghunus pedang, dan menghalalkan peperangan, melawan umat Islam. Kita tidak boleh terkecoh dengan bacaan al-Qur'an, lamanya shalat, shaum, dan keindahan retorika mereka, jika doktrin mereka adalah doktrin Khawarij. ${ }^{18}$ Dari sepak terjang pemahaman kaum Khawarij dari dulu hingga sekarang, maka dapat di tarik garis lurus bahwa doktrin Khawarij dapat dikategorikan tiga, yaitu:

${ }^{18} \mathrm{Abū}$ Bakar Muhammad ibn Husain al-'Ājurrī, al-Shari'ah (Riyaḍ: Dār al-Wațan, 1999). 


\section{Doktrin Politik}

Dikatakan doktrin politik oleh karena secara praktis-yakni kemahiran bernegara, atau kemahiran berupaya menyelidiki manusia dalm memperoleh kekuasaan, atau kemahiran mengenai latar belakang, motivasi, dan hasrat mengapa manusia ingin memperoleh kekuasaan. Khawarij dapat dikatakan sebagai sebuah partai politik.

Politik merupakan doktrin sentral Khawarij yang timbul sebagai reaksi terhadap keberadaan Muawiyah yang secara teoritis tidak pantas memimpin negara, karena ia adalah seorang tulaqa (bekas kaum musyrikin di Mekkah yang dinyatakan bebas pada hari jatuhnya kota itu kepada kaum Muslimin).

Kebencian itu bertambah dengan kenyataan bahwa keislaman Muawiyah belum lama. Mereka menolak untuk dipimpin orang yang dianggap tidak pantas. Jalan pintas yang ditempuhnya adalah membunuhnya, termasuk orang yang mengusahakannya menjadi Khalifah. Dikumandangkanlah sikap bergerilya untuk membunuh mereka

Doktrin-doktrin politik yang menjadi sentral kaum Khawarij adalah: a) Khalifah atau imam harus dipilih secara bebas oleh seluruh umat islam; b) Khalifah tidak harus berasal dari keturunan Arab. Dengan demikian setiap orang Muslim berhak menjadi khalifah apabila sudah memenuhi syarat; c) Khalifah dipilih secara permanen selama yang bersangkutan bersikap adil dan menjalankan syariat islam. Ia harus dijatuhkan bahkan dibunuh kalau melakukan kezaliman; d) Khalifah sebelum Ali adalah sah, tetapi setelah tahun ke tujuh dari masa kekhalifahannya, Utsman dianggap telah menyeleweng; e) Khalifah Ali adalah sah tetapi setelah tahkim, ia dianggap telah menyeleweng. Muawiyah dan Amr ibn Ash serta Abu Musa al-Asy'ari juga dianggap menyeleweng dan teleh menjadi kafir; f) Pasukan perang Jamal yang melewati Ali juga kafir.

\section{Doktrin Teologi}

Doktrin teologi tentang dosa besar sebagaimana tertera pada poin di bawah berikut. Akibat doktrinnya yang menentang pemerintah, Khawarij harus menanggung akibatnya. Mereka selalu dikejar-kejar dan diperangi oleh pemerintah. Kemudian perkembangannya, selanjutnya sebagaimana dikatakan Harun Nasution, kelompok ini sebagian besar sudah musnah. Sisa-sisanya terdapat di Zanzibar, Afrika Utara, dan Arabia Selatan. 
Doktrin teologi Khawarij yang radikal pada dasarnya merupakan imbas langsung dari doktrin sentralnya, yakni doktrin politik. Radikalitas itu sangat dipengaruhi oleh sisi budaya mereka yang juga radikal serta asal-usul mereka yang berasal ari masyarakat Badawi dan pengembara padang pasir tandus. Hal itu menyebabkan watak dan pola pikirnya menjadi keras, berani, tidak bergantung pada orang lain, dan bebas.

Namun, mereka fanatik dalam menjalankan agama. Sifat fanatik itu biasanya mendorong seseorang berpikir sempit, berpengetahuan sederhana, melihat pesan berdasarkan motivasi pribadi, dan bukan berdasarkan pada data dan konsitensi logis, bersandar lebih banyak pada sumber pesan (wadah) daripada isi pesan, mencari informasi tentang kepercayaan orang lain dari seumber kelompoknya dan bukan dari sumber kepercayaan orang lain, mempertahankan secara kaku sistem kepercayaannya, dan menolak, mengabaikan, dan mendistorsi pesan yang tidak konsisten dengan sistem kepercayaannya. Orangorang yang mempunyai prinsip Khawarij ini menggunakan kekerasan dalm menyalukan aspirasinya. Sejarah mencatat bahwa kekerasan pernah memegang peran penting.

Doktrin-doktrin teologi yang dianut oleh kaum Khawarij antara lain: a) Seorang yang berdosa besar tidak lagi disebut Muslim sehingga harus di bunuh. Mereka menganggap bahwa seorang Muslim dapat menjadi kafir apabila ia tidak mau membunuh Muslim lain yang telah dianggap kafir dengan resiko ia menanggung beban harus dilenyapakan pula; b) Setiap Muslim harus berhijrah dan bergabung dengan golongan mereka. Bila tidak mau bergabung, ia wajib diperangi karena hidup dalam dār al-ḥarb (negara musuh), sedang golongan mereka sendiri dianggap dār al-Islām (negara Islam); c) Seseorang harus menghindari pimpinan yang menyeleweng; d) Adanya wa'ad dan waïd (orang yang baik harus masuk surga sedangkan orang yang jahat masuk ke dalam neraka).

\section{Doktrin Teologis Sosial}

Doktrin ini memperlihatkan kesalehan asli kelompok Khawarij sehingga sebagian pengamat menganggap doktrin ini lebih mirip dengan doktrin Mu'tazilah, meskipun kebenarannya adalah doktrin ini dalam wacana kelompok Khawarij patut dikaji mendalam.

Orang-orang yang keras dalam pelaksanaan ajaran agama, sebagaimana dilakukan kelompok Khawarij, cenderung berwatak tekstualis/skripturalis se- 
hingga menjadi fundamentalis. Kesan skriptualis dan fundamentalis itu tidak nampak pada doktrin-doktrin Khawarij. Namun, bila doktrin teologis-sosial ini benar-benar merupakan doktrin Khawarij, dapat diprediksikan bahwa kelompok Khawarij pada dasarnya merupakan orang-orang baik. Hanya saja, keberadaan mereka sebagai kelompok minoritas penganut garis keras, yang aspirasinya dikucilkan dan di abaikan penguasa, ditambah oleh pola pikirnya yang simplistis, telah menjadikan mereka bersikap ekstrim, dank eras terhadap umat Islam.

Menurut hadis Rasulullah, bahwa Khawarij akan nampak sangat beragama. Mereka terus-menerus melakukan shalat, puasa, serta ibadah-ibadah lain lebih dari umat Islam pada umumnya. Mereka kelihatan lebih kaku memahami hukum Islam. Rasulullah bersabda:

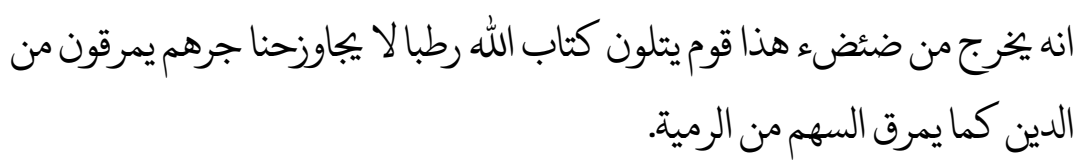

Sesungguhnya akan keluar dari keturunan laki-laki ini suatu kaum yang membaca kitabullah dengan fasih, tetapi hanya sebatas di kerongkongan mereka. Mereka keluar di agama Islam seperti anak panah yang melesat di busurnya. ${ }^{19}$

Rasulullah bersabda, bahwa akan muncul di akhir zaman suatu kaum yang mereka terdiri dari anak-anak muda, berpikiran dangkal, berkata dengan perkataan yang indah, membaca al-Qur'an yang hanya sebatas kerongkongan mereka saja. Mereka keluar dari agama (Islam) seperti anak panah yang melesat dari busurnya. Apabila kalin menjumpai mereka, maka bunuhlah, karena membunuh mereka memiliki pahala di sisi Allah pada hari kiamat. ${ }^{20}$

Abū Sa'id al-Khudriy berkata bahwa Rasulullah bersabda:

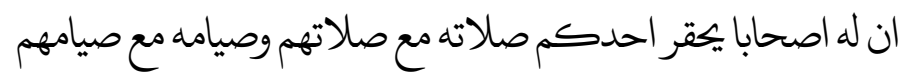

${ }^{19}$ HR. Bukhāri, dalam al-Șahịh; Kitab al-Maqhāz̄i, Bab; Mengutus Ali ibn Abi Thalib dan Khalid ibn Walid sebelum Haji Wada', 4: 1581, hadis no. 4094.

${ }^{20}$ HR. Bukhāri dalam al-Sahịh; Kitab Anjuran Bertobat dan memerangi para Murtadin dan Perusuh, Bab. Memerangi Khawarij dan Kaum Bid'ah Setelah ada Bukti yang Membolehkan untuk Menumpas Mereka Juz. 6:2539 hadis no. 5531. 
Sesungguhnya dia memiliki teman-teman yang salah seorang dari kalian akan merasa minder dengan shalatnya jika dibandingkan dengan shalat mereka dan shaumnya jika dibandingkan dengan shaum mereka. ${ }^{21}$

\section{F. Bid'ah Khawarij}

Sebagaimana dipahami bahwa Khawarij tidak memiliki posisi apapun dalam ajaran agama Islam. Mereka melakukan berbagai bid'ah atas nama agama. Sejarah membuktikan bahwa Khawarij memiliki keyakinan, ideologi, dan bid'ah yang sangat ekstrim. Akhir-akhir ini muncul kembali benih-benih generasi Khawarij di beberapa negeri kaum Muslimin. Kaum Muslimin harus waspada terhadap fenomena tersebut! Agar orang yang memiliki secercah ilmu dapat mengidentifikasi hakikat permasalahan, dapat menetapkan hukum secara benar dan dapat membedakan antara kesalahan yang bisa dimaklumi dan kesalahan yang tidak bisa dimaklumi, yaitu kesalahan yang berpangkal dari asas ahlu bid'ah. Khususnya bid'ah yang berkaitan dengan masalah pengkafiran kaum Muslimin, penghalalan darah, harta dan tempat tinggal mereka.

Sebuah pemikiran dan ideologi tidak akan mati, meskipun para penganutnya sudah terkubur hancur dimakan tanah! Demikianlah sebuah ungkapan yang sering kita dengar dan tidak asing lagi di telinga kita. Memang begitulah realitanya, sebagai contoh pemikiran Khawarij yang masih tetap eksis hingga sekarang bahkan benih-benih pemikirannya masih tetap bertahan. Begitu pula pada hari ini, meskipun para alim ulama telah memperingatkan umat dari bahaya bid'ah Khawarij ini,

Mayoritas orang-orang yang terjebak dalam bid'ah Khawarij pada awalnya tidak menyadari bahwa pemikiran yang bercokol dalam benaknya adalah benihbenih bid'ah Khawarij. Setelah larut di dalamnya dan setelah terbawa arus dan telah terkondisi, mereka tidak dapat melepaskan diri darinya. Sebagai contoh sekarang ini muncul sebuah pemikiran bahwa dalam menjatuhkan vonis kafir terhadap seseorang sekarang ini tidak dibutuhkan lagi proses penegakan hujjah.

Contoh pemikiran lainnya, dalam menetapkan bahwa seseorang telah menghalalkan dosa yang dilakukannya cukup dengan qarinah (indikasi kuat) bahwa mereka menghalalkannya.. Karena mereka hanya menerima istilah

${ }^{21}$ HR. Bukhāri dalam al-Ṣaḥịh, Kitab Tatakrama, Bab: hadis-hadis tentang "celakalah kalian', $5 ; 2281$ hadis no. 5811. 
menghalalkan hukum selain hukum Allah dari lubuk hatinya. Adapun indikasiindikasi yang terlihat dari amal perbuatan mereka jelas menunjukkan bahwa mereka menghalalkan hal itu. Bahkan menunjukkan kekufuran dan penghinaan terhadap hukum Allah tersebut, Melihat gejala yang tumbuh di tengah-tengah umat yaitu maraknya pemikiran-pemikiran bid'ah Khawarij khususnya di kalangan pemuda.

Al-Shahrastān, mengatakan bahwa orang Khawarij yang pertama dari kelompok ini bernama $\mathrm{Zu}$ al-Khuwairisah, dan yang terakhir adalah $\mathrm{Zu}$ alTsadiyah. Mereka menyatakan bahwa mereka tidak menaati khalifah semenjak awalnya karena itu mereka telah menciptakan dua macam bid'ah.

Pertama, bid'ah yang mereka buat tentang imamah. Menurut mereka imam boleh saja selain dari Quraisy. Setiap orang yang mereka angkat yang mampu berlaku adil dan menjauh dari kejahatan adalah imam yang sah setiap yang tidak menaatinya wajib dibunuh. Apabila imam telah berubah perilakunya dan telah meninggalkan kebenaran wajib diberhentikan atau dibunuh. Kelompok ini termasuk orang yang paling banyak mempergunakan kias dan menurut mereka tidak boleh ada dua orang imam dalam satu zaman. Hanya dalam keadaan yang sangat terpaksa dapat diangkat menjadi imam lebih dari satu orang. Baik dari orang yang merdeka atau budak atau orang biasa atau dari keturunan Quraisy.

Kedua, Ali ibn Abi Thalib menurut mereka telah banyak melakukan kekeliruan di antaranya menerima konsep arbitrase yakni menerima hukum yang dibuat manusia bukan hukum Allah. Mereka menolak sikap Ali ibn Abi Thalib dari dua sisi; pertama; tentang arbitrase. Menurut mereka arbitrase (tahkim) adalah hasil keputusan manusia yang tidak menjamin kebenaran. Padahal pada mulanya mereka itulah yang mendorong Ali ibn Abi Thalib menerima konsep arbitrase. Kedua; menurut mereka arbitrase boleh saja dari orang yang ahli dan mampu dalam masalah itu. Ali ibn Abi Thalib pernah berkata terhadap kelompok ini, di lihat dari ucapan mereks berada di pihak yang benar. Namun di balik itu dimaksudkan kebatilan. Mereka sudah jauh dari menyimpang dari ajaran yang benar. Bahkan lebih mendekati kepada kekafiran. Karena Ali ibn Abi Thalib mengutuk kelompok dan memeranginya, merampas harta kekayaan, menawan anak dan wanita mereka.

\section{G. Kesimpulan}

Khawarij adalah aliran pengikut Ali ibn Abi Thalib yang keluar meninggalkan barisan karena ketidaksepakatan terhadap Ali yang menerima arbitrase. 
Khawarij terbagi golongan kecil yang terdiri dari delapan golongan antara lain : al-Muhakkimah, al-Azariqah, al-Nadjah, al-Baihasiyah, al-Ajaridah, al-Tha'labiyah, al-Ibadilyah, dan al-Sufriah,

Secara komprehensif dapat digambarkan paham ideologi, keyakinan, dan bid'ah kaum Khawarij, yaitu; mereka adalah kaum muda yang berpikiran dangkal, mereka memakai kain (celana) yang menggantung di atas mata kakinya. Iman mereka hanya sebatas kerongkongan (keimanan mereka sangat dangkal dan kualitas iman mereka tidak sesuai dengan tampilan lahiriyahnya. Mereka sangat berlebihan dan kaku dalam urusan agama. Orang mu'min akan merasa rendah diri jika membandingkan shalat dan shaumnya dengan shalat dan shaum mereka orang-orang Khawarij. Bacaan al-Qur'an mereka hanya sebatas kerongkongan. Mereka akan berkata dengan perkataan manusia yang paling baik (artinya mereka akan menggunakan slogan agama dan perintahperintah agama). Seluruh pemerintahan Islam dianggap kafir dan tersesat. Mereka akan muncul ketika manusia berada dalam konplik.

Mereka menumpahkan darah, membunuh warga sipil Muslim dan nonMuslim adalah dibolehkan. Mereka menyatakan wajib untuk menggelorakan pemberontakan bersenjata melawan pemerintah buruk dan dzalim. Mereka mengatakan bahwa Muslim yang melakukan dosa besar adalah kafir. Mereka mengatakan bahwa membunuh dan menjarah Muslim pelaku dosa besar adalah halal. []

\section{DAFTAR PUSTAKA}

Ahmad 'Usmānī, Syabbīr, al-Fatḥ al-Mulkin bi Sharh Șahịḥ Muslim, Damaskus: Dār al-Qolam, 2006.

al-'Aini, Badri al-Din, Umdah al-Qari Sharh Șaḥịh al-Bukhāri, Beirut: Dar Ihya alTurats al-'Arabi, t.th.

al-'Ājurrī. Abū Bakar Muhammad ibn Husain, al-Shari'ah, Riyad: Dār al-Wathan, 1999.

Ali ibn Muhammad ibn al-Athīr, al-Kāmil fi al-Tarīk, Beirut: Dār Shādir, 1979.

al-Asqalānī, Ibnu Hajar Ahmad ibn 'Ali, Hadyu al-Sari: Muqaddimah Fatḥ Bāri, Beirut: Dar al-Ma'rifah, t.th. 
Bukhārī, 'Abū 'Abdi Allāh Muhammad ibn Ismāil ibn Ibrāhīm ibn Mughīrah, alJāmi al-Ṣahīh, Beirut: Dār Ibnu Katsīr, 1987.

Ibnu Taimiyah, Ahmad ibn 'Abdi Al-Halim, al-Nubuwwat, Beirut: Dār Al-Kitab Al'Arabi, 1985. Majmä'al-Fatāwā, Maktabah, Ibnu Taimiyah, t. th..

al-Nawawi, Muhyi al-Dīn Yahya ibn Sharaf, Sharḥu al-Nawāwī 'alā Ṣaḥịh Muslim, Beirut: Dār Ihya al-Turāts, 1392.

Nasution, Harun, Teologi Islam: Aliran-aliran Sejarah Analisa Perbandingan, Jakarta; UI-Press, 1986.

al-Qadri, Muhammad Tahir, Fatwa tentang Terorisme dan Bom Bunuh Diri, Jakarta: LPPI, 2014.

al-Shahrastāni, Muhammad ibn 'Abdu al-Karim, al-Milāl wa al-Niḥāl, Beirut: Dar al-Ma'rifah, 2000.

'Usmānī, Shabbīr Aūmad, al-Fath al-Mu'în bi Sharh Shahih Muslim (Damaskus: Dār al-Qalam, 2006),

Zahra, Muhammad Ahmad Abu, al-Mazāhib al-Islāmiyyah, Maktabah al-Adab, Kairo, t.th. 
430 JURNAL THEOLOGIA — Volume 27, Nomor 2, Desember 2016 